Emir. J. Food Agric. 2008. 20 (1): 46-59

http://www.cfa.uaeu.ac.ae/research/ejfa.htm

\title{
Phenotypic identification and technological properties of lactic acid bacteria isolated from three breeds dromedary raw milks in south Algeria
}

\author{
Hassaïne, O., H. Zadi-Karam and N-E. Karam
}

Laboratoire de Biologie des Microorganismes et de Biotechnologie, Department of Biotechnology, Faculty of Sciences, Oran University (Es-sénia), Oran, Algeria

\begin{abstract}
A total of 9 samples of individual dromedary raw milks from N'ajjer (3 samples), Targui (3 samples) and Reguibi (3 samples) breeds were collected from 3 camels nomad herd in south Algeria and were analysed for bacterial load. A total of 23 isolates of lactic acid bacteria were obtained and characterized; 12 isolates were cocci and 11 isolates were facultatively heterofermentative lactobacilli. Lactic acid bacteria were identified on the basis of phenotypic characters as Lactococcus lactis subsp. lactis, Enterococcus faecalis, Enterococcus faecium, Enterococcus durans, Lactobacillus paracasei subsp. paracsei, Lactobacillus plantarum and Lactobacillus rhamnosus. Lactococci, enterococci and lactobacilli showed proteolytic activity and were found that differ in their acidifying activities. Proteolytic and autolytic activities were generally higher for most lactobacilli compared to other isolates and none of the isolates produced biogenic amines under the conditions tested. A number of the 23 lactic acid bacteria isolates from Algerian dromedary milks that were characterized here showed properties suggest that they are good candidates for camels milk processing or other dairy fermentation process.
\end{abstract}

Keywords: Algerian dromedary milks, Lactic acid bacteria, Identification, Acidification, Proteolysis, Autolysis.

$$
\begin{aligned}
& \text { التعريف النوعي والخصائص التكنولوجية لبكتريا حامض اللاكتيك التي تم عزلها من }
\end{aligned}
$$

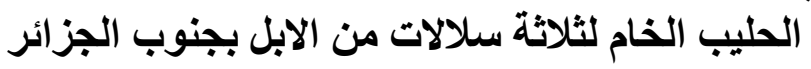

$$
\begin{aligned}
& \text { و. حسين، هـ. زادى- كرم، ن- اي. كرم } \\
& \text { قسم الكيمياء الحيوية، كلية العلوم، جامعة وران، وران، الجزائر } \\
& \text { الملخص: تم جمع تسعة عينات من حليب الإبل الخام (ثلاثة عينات من ثلاثة أنو اع من الجمال وحيدة السنام بجنوب الجز ائر } \\
& \text { و تحليلها لمعرفة حملها البكتيري. تم عزل وتصنيف } 23 \text { نوع من بكتريا حامض اللاكتيك (Reguibi - Targui -N'ajjer) } \\
& \text { ، } 12 \text { من البكتريا الكروية و } 11 \text { من البكتريا العصوية الاختيارية مختلطة التخمر. تم التعرف على بكتريـا حامض اللاكتيك }
\end{aligned}
$$

اعتمـادا على الخصائص النوعية وتشمل : Lactococcus lactis subsp. Lactis, Enterococcus faecalis,

Enterococcus faecium, Enterococcus durans, Lactobacillus paracasei subsp. Paracsei, actobacillus plantarum and Lactobacillus rhamnosus.

$$
\begin{aligned}
& \text { في خصائص تحليل البروتينات وتختلف في قدرنها لإنتاج الاحماض. قدرة بكتريـا حامض اللاكتيك العصوية على تحليل } \\
& \text { البروتينات و التحلل الذاتي مرتفعة بالمقارنة مع البكتريا الأخرى. كل البكتريا المعزولـة لبس لها القدرة على انتاج الأمينـات } \\
& \text { الحيويـة في ظروف الاختبار. تم عزل وتصنيف } 23 \text { نوع من بكتريـا حـامض اللاكتيك من حليب الجمـال وحيدة السنام } \\
& \text { الجزائرية و أظهرت خصائص تجعلها صالحة للاستخدام في تصنيع حليب الإبل و التخمر ات اللبنية الأخرى. } \\
& \text { الكلمات المفتاحية: حليب الابل الجزائري، بكتريا حامض اللاكتيك، تعريف، تحمض، تحلل البروتين، تحلل الذاتي. }
\end{aligned}
$$




\section{Introduction}

Development and research activities on domestic animals are mostly concentrated on species and breeds of animals available in the temperate zones of Europe and North America. This results in a relative neglect of several species of animals native to the tropics and subtropics. The camel (Camelus dromedarius) is certainly one of the most neglected species of the domestic animals. The majority of the studies conducted on camels concentrate mainly on its anatomical features and physiological adaptations to desert conditions. Information about camels as milk animals is very limited. Camel milk is important to the human diet in many parts of the world. People unfamiliar with camels are surprised to learn that a normal camel on good feed can produce 2000 litres of milk per lactation period (Yagil, 1982), and even higher milk yields have been recorded (Knoess, 1980).

In pastoral societies, milk is traditionally consumed predominantly in the form of fermented milk. Fermentation is the only means of preserving milk under warm condition. In many arid areas camels play a central role as milk suppliers, there is either home-consumed or sold.

To prepare fermented camel milk, containers of calabas, cly potes, plant fibre vessels or hollowed wood vessels are smoked by burning chips of Olea Africana or Acacia busia. The daily residual fresh milk is poured into the milk container. No starters are used and acidification develops after a few days, either from natural flora of milk when it is not boiled, or from the bacteria growing on the sides of the vessel. The milk is left in a quiet place, often in a covered container sheltered from dust for usually 24-48 hours until it becomes sour. The ambient temperature is normally between 25 and $35^{\circ} \mathrm{C}$. Due to spontaneous nature of the fermentation, this traditional method results in a product with varying taste and flavour and often of poor hygienic quality.

They improve this spontaneous traditional fermentation, controlled fermentation using mesophilic lactic acid bacteria starter cultures that originated from this ecosystem is a very important strategy for camel milk processing. This work was therefore aimed for isolation and characterization of lactic acid bacteria from raw milks of three breeds of Algerian dromedary and evaluated for their technologically important properties.

\section{Materials and Methods}

\section{Sampling}

A total of nine individual dromedary raw milk samples from N'ajjer (3 samples), Targui (3 samples) and Reguibi (3 samples) breeds were collected aseptically from three camels' nomad herd in the regions of Tin-Guentourin (Illizi), Tin-Zaiatin (Ain Amenas) and Tindouf in south Algeria. The nipples of the female camel were rinsed with some water chlorinated and rinsed then with some sterile water. The first jets of milk are eliminated and then samples of 150 to $200 \mathrm{ml}$ were collected in a sterile flask, each sample representing the pooled milk from one single milking of each herd, were immediately cooled, and brought to the laboratory in an isotherm container, being analyzed on arrival.

\section{Isolation and Identification of Strains}

Ten millilitres of milk sample were vigorously mixed with nine volumes of sterile diluent $\left[1 \mathrm{~g} \mathrm{l}^{-1}\right.$ bacteriological peptone, $\left.8.5 \mathrm{~g} \mathrm{l}^{-1} \mathrm{NaCl}\right]$ and serial 10fold dilutions $\left(10^{-1}\right.$ to $\left.10^{-8}\right)$ were prepared using the same diluent.

One millilitre of these dilutions was pour-plated in the media for lactic acid bacteria i.e. M17 (Terzaghi and Sandine, 1975) and MRS (de Man et al., 1960) adjusted to $\mathrm{pH}$ 5.5. 
After incubation at $30^{\circ} \mathrm{C}$ for $24 \mathrm{~h}$ and three days, respectively, representative isolates of lactic acid bacteria were obtained from M17 and MRS plates of highest sample dilutions.

Colonies were either randomly picked up or all sampled when the plate contained less than 10 colonies (Leisner et al., 1997). The purity of the isolates was checked by streaking again to fresh agar plates, followed by macroscopic and microscopic examinations. The strains displaying the general characteristics of lactic acid bacteria were chosen from each plate for further studies.

The isolates of lactic acid bacteria were stored without appreciable loss of properties in skimmed milk at $-20^{\circ} \mathrm{C}$. The working cultures were also kept on MRS agar or M17 agar slant at $4^{\circ} \mathrm{C}$ and streaked every four weeks (Samelis et al., 1994; Herrero et al., 1996).

Cell morphology and mobility of all isolates of lactic acid bacteria were observed using a phase contrast microscope following the method of Harrigan (1998). Isolates were Gramstained and tested for catalase production. Preliminary isolation and grouping was on the basis of cell morphology and phenotypic properties using gas production from glucose, determined in M17 and MRS broth containing inverted Durham; growth at different temperatures $\left(10^{\circ} \mathrm{C}, 15^{\circ} \mathrm{C}, 37^{\circ} \mathrm{C}\right.$ and $\left.45^{\circ} \mathrm{C}\right)$, and at $\mathrm{pH}$ 9,6 as well as the ability to grow in the different concentrations of $\mathrm{NaCl}(2 \%, 3$ $\%, 4 \%$ and $6.5 \% \mathrm{NaCl}$ ); Sherman test and survival after heating of $60^{\circ} \mathrm{C}$ for 30 min (Samelis et al., 1994); hydrolysis of arginine, tested on M17 and MRS with bromocresol purple (Thomas, 1973); and production of acetoïn from glucose, determined by using the Voges-Proskauer test (Zourari et al., 1991).

The fermentation of carbohydrates was determined in MRS and M17 broth without glucose and meat extract and with $0.04 \mathrm{~g} \mathrm{l}^{-1}$ bromocresol purple and phenol red respectively as $\mathrm{pH}$ indicator, and supplemented with $10 \mathrm{~g} \mathrm{l}^{-1}(\mathrm{w} / \mathrm{v})$ of the following carbohydrates: glucose; arabinose; cellobiose; galactose; sucrose; lactose; maltose; mannitol; melizitose; melibiose; raffinose; rhamnose; ribose; trehalose; D-xylose; sorbitol (Sigma). To ensure anaerobic conditions, each tube was topped up with two drops of sterile liquid paraffin after incubation (Samelis et al., 1994). Tests for phenotypic characterization were conducted twice for each strain.

\section{Technological Properties Acidification Ability}

The isolates were initially grown in MRS (rods) or M17 (cocci) broth and then in sterile reconstituted skim milk supplemented with yeast extract $\left(3 \mathrm{~g} \mathrm{l}^{-1}\right)$ and glucose $\left(2 \mathrm{~g} \mathrm{l}^{-1}\right)$ for two successive subcultures. Sterile reconstituted skim milk $(100 \mathrm{ml})$ was inoculated with $1 \%$ $(\mathrm{v} / \mathrm{v})$ of a $24 \mathrm{~h}$ activated culture and $\mathrm{pH}$ changes were determined using $\mathrm{pH}$ meters (glass electrode, HANNA instruments, Padova, Italy) during incubation at $30^{\circ} \mathrm{C}$ after $6 \mathrm{~h}$ for lactococci and lactobacilli and after $5 \mathrm{~h}$ for enterococci.

The $\mathrm{pH}$ of the culture was also measured after $18 \mathrm{~h}$ for lactococci and/or $24 \mathrm{~h}$ for lactobacilli and enterococci (Durlu-Ozkaya et al., 2001).

\section{Proteolytic Activity}

Surface-dried plates of milk agar (Gordon et al., 1973) were streaked with 24-h-old culture, incubated at $30^{\circ} \mathrm{C}$ for four days, and examined for any halo of proteolysis around and underneath the growth for assessment of proteolytic activity. After $72 \mathrm{~h}$ of incubation in the skimmed milk, the proteolytic activity (expressed as free amino acids in the medium) was evaluated at $507 \mathrm{~nm}$ after reaction with Cd-ninhydrin (Folkertsma and Fox 1992) with a UV-visible spectrophotometer (Varian, Australia). Free amino groups were quantified as standard $\mathrm{m} \mathrm{mol}^{-1}$ equivalency of 
Glycine per litre of milk (meq Gly/l) (Bouton et al., 1993).

\section{Autolytic Activity}

The isolates were cultivated in MRS (rods) or M17 (cocci) broth and the obtained pellets by centrifugation were washed twice in potassium phosphate buffer (10 m mol $\mathrm{m}^{-1}, \mathrm{pH} \mathrm{7.0)}$ and then resuspended in potassium phosphate buffer (10 $\left.\mathrm{m} \mathrm{mol}^{-1}, \mathrm{pH} 5.5\right)$ containing 1 mol $1^{-1} \mathrm{NaCl}$ and diluted to $\mathrm{OD}_{650}$ equal 1,0 . The rate of autolysis was determined according to the method described by Thiboutot et al., (1995). The cell suspension was subjected to one cycle of freezing $\left(-20^{\circ} \mathrm{C}\right.$ for $\left.24 \mathrm{~h}\right)$ and thawing then incubated at $37^{\circ} \mathrm{C}$. The autolytic activity was determined as the percentage decrease in the absorbance at $650 \mathrm{~nm}$ at different time intervals as described by Boutrou et al., (1998), which was defined as follows: $\left(A_{0}-A_{t}\right) \times 100 / A_{0}$ where $A_{0}$ $=$ initial absorbance, and $A_{t}=$ absorbance measured after $t$ days of incubation.

Autolysis was ranked in accordance to the activity level of each genus; lactococci; good 25-37; fair 15-24; poor 1-14, lactobacilli; good 70-96; fair 40-69; poor 0-39 and enterococci; good 35-66; fair 24-34; poor $0-22$, as described by Ayad et al. (2004).

\section{Decarboxylase Activity}

The ability of the test strains to decarboxylate histidine, tyrosine, lysine and ornithine, was determined as described by Joosten and Northolt (1989).

\section{Results and Discussion}

\section{Identification of Isolates}

The physiologic characteristics of the strains (which we studied) are shown in Table 1. Out of a total of 37 Isolates obtained from raw dromedary milks from three local breeds [N'ajjer (14 isolates), Targui (12 isolates) and Reguibi (11 isolates)], twenty-three strains showed positive Gram reactions, absence of mobility, absence of spore formation, absence of catalyse activity cocci which produced no gas from glucose (12 isolates), and/or rods (11 isolates). Among the cocci, five isolates were presumptively identified as $L$. lactis subsp. lactis, they were able to grow at 10 and $37^{\circ} \mathrm{C}$, but not at $45^{\circ} \mathrm{C}$, and not in $\mathrm{pH} 9.6$ broth. In addition all of the five isolates could grow in $4 \% \mathrm{NaCl}$ broth but not in $6 \%$, they did not also survive at $60^{\circ} \mathrm{C}$ for $30 \mathrm{~min}$, and produced $\mathrm{NH}_{3}$ from arginine. All the isolates formed acid from lactose, and ribose but acid production from mannitol, sucrose and xylose was strain dependent. (Sharpe, 1979; Schleifer et al., 1985; Balows et al., 1991). Seven isolates of cocci were able to grow at 10 and $45^{\circ} \mathrm{C}$, in $6.5 \% \mathrm{NaCl}$ and $\mathrm{pH} 9.6$ broth, they also survive at $60^{\circ} \mathrm{C}$ for $30 \mathrm{~min}$ and formed $\mathrm{NH}_{3}$ from arginine, but not $\mathrm{CO}_{2}$ from glucose and were characterized as enterococci. Three of them seemed to be E. faecalis, as suggested by their ability to survive at $60^{\circ} \mathrm{C}$ for $30 \mathrm{~min}$ and to ferment sorbitol (Sharpe, 1979; Shleifer and Kilpper-Balz, 1984; Devriese et al., 1991; Manero and Blanch, 1999). Four enterococci isolates differed in their ability to form acid from sugars. Three isolates produced acid from mannitol and arabinose and were thus characterized as E. faecium. One isolate was characterized by inability to ferment melibioze and sucrose and unable, in general, to ferment sugars and was thus classified as E. durans (Schleifer and Kilpper-Balz, 1984; Devriese et al., 1991; Manero and Blanch 1999).

The 11 isolates of Gram-positive rods grew at $15^{\circ} \mathrm{C}$ and did not form either $\mathrm{CO}_{2}$ from glucose or $\mathrm{NH}_{3}$ from arginine. These characteristics suggest their classification as facultatively heterofermentative lactobacilli (Sharpe, 1979; Balows et al., 1991). Two out of 11 isolates did not form acid from arabinose, melibiose, raffinose and rhamnose and were characterized as $L b$. paracasei subsp. pracasei (Collins et al., 1991; 
Emir. J. Food Agric. 2008. 20 (1): 46-59

http://www.cfa.uaeu.ac.ae/research/ejfa.htm

Balows et al., 1991). A total of five isolates of rods were classified as $L b$. plantarum, as suggested by their sugar fermentations patterns. All these isolates fermented arabinose, cellobiose, lactose, maltose, melibiose, raffinose, ribose, sucrose and trehalose (Sharpe, 1979; Balows et al., 1991). These isolates did

not form acid from rhamnose and acid production from sorbitol and xylose was variable and strain dependant. The last four isolates were unable to ferment melibiose, raffinose, xylose, sucrose and arabinose and able to form acid from rhamnose and were classified as $L b$. rhamnosus.

Table 1. Phenotypic characteristics of lactic acid bacteria isolated from dromedary raw milks.

\begin{tabular}{|c|c|c|c|c|c|c|c|}
\hline Identified as & 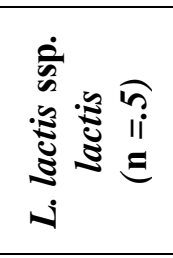 & 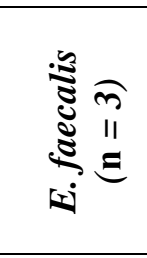 & 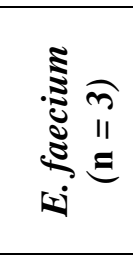 & 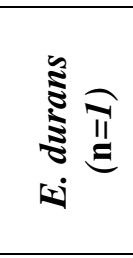 & 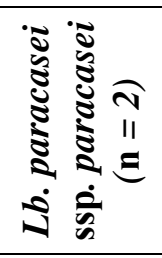 & 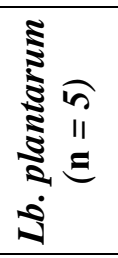 & 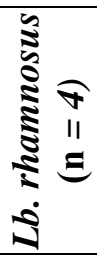 \\
\hline Gram & + & + & + & + & + & + & + \\
\hline Catalase & - & - & - & - & - & - & - \\
\hline Morphology & Cocci & Cocci & Cocci & Cocci & Rods & Rods & Rods \\
\hline Production of $\mathrm{CO}_{2}$ from glucose & - & - & - & - & - & - & - \\
\hline Growth at $\mathrm{pH} 9,6$ & - & + & + & + & & & \\
\hline \multicolumn{8}{|l|}{ Growth at } \\
\hline $10^{\circ} \mathrm{C}$ & + & + & + & + & & & \\
\hline $15^{\circ} \mathrm{C}$ & + & + & + & + & + & + & + \\
\hline $37^{\circ} \mathrm{C}$ & + & + & + & + & & & \\
\hline $45^{\circ} \mathrm{C}$ & - & + & + & + & $+/-$ & - & + \\
\hline \multicolumn{8}{|l|}{ Growth at } \\
\hline $2 \% \mathrm{NaCl}$ & + & + & + & + & & & \\
\hline $3 \%$ & + & + & + & + & & & \\
\hline $4 \%$ & + & + & + & + & & & \\
\hline $6,5 \%$ & - & + & + & + & - & - & - \\
\hline Sherman test & + & + & + & + & & & \\
\hline Hydrolyse of Arginine (ADH) & + & + & + & + & - & - & - \\
\hline Survival at $60^{\circ} \mathrm{C}$ for $30 \mathrm{~min}$ & - & + & + & + & & & \\
\hline Acetoin (VP) & + & + & + & + & & & \\
\hline \multicolumn{8}{|l|}{ Acid from: } \\
\hline Glucose & + & + & + & + & + & + & + \\
\hline Lactose & + & + & + & + & + & + & + \\
\hline Galactose & + & + & + & + & + & + & + \\
\hline Sorbitol & - & + & - & - & + & + & + \\
\hline Melibiose & - & - & + & - & - & + & - \\
\hline Raffinose & - & - & - & - & - & + & - \\
\hline Xylose & + & - & - & - & - & + & - \\
\hline Sucrose & + & + & + & - & + & + & - \\
\hline Arabinose & - & + & + & - & - & + & - \\
\hline Melezitose & - & - & - & - & + & + & + \\
\hline Rhamnose & - & $+/-$ & - & - & - & - & + \\
\hline Maltose & + & + & + & + & + & + & + \\
\hline Ribose & + & + & + & + & + & + & + \\
\hline Mannitol & + & + & + & - & + & + & + \\
\hline Trehalose & + & + & + & + & + & + & + \\
\hline Cellobiose & + & + & + & + & + & + & + \\
\hline
\end{tabular}




\section{Acidification Ability and Proteolytic Activity}

With respect to the acidifying activity of the strains (Figure 1) it seems that none of the L. lactis subsp. lactis strains can be characterized as fast fermenters, as it took $>6 \mathrm{~h}$ at $30^{\circ} \mathrm{C}$ for them to reach a $\mathrm{pH}$ of $5.0 \pm 0.2$ (Huggins and Sandine, 1984). All isolates were faster initially acidifying $(6 \mathrm{~h})$ and the $\mathrm{pH}$ drop after 18 $\mathrm{h}$ ranged from 1.65 and $2.10 \mathrm{pH}$ units, except for isolate DT11, which showed higher acidifying activity (a drop of 2.32 $\mathrm{pH}$ units after $18 \mathrm{~h}$ ).

Lactobacillus isolates differed in their ability to reduce the $\mathrm{pH}$ of milk initially and there were isolates that did not change the $\mathrm{pH}$ of milk at $6 \mathrm{~h}$. Nevertheless, after $24 \mathrm{~h}$ incubation the drop in $\mathrm{pH}$ after $24 \mathrm{~h}$ of the isolates were similar and ranged between 0.88 and 1.35 , except for isolate DT18, which had a drop in $\mathrm{pH}$ after $24 \mathrm{~h}$ of 1.61 . Lactobacillus casei and Lactobacillus plantarum may ferment lactose through a $\beta$-galactosidase activity, but some strains also show a $\beta$-phospho-galactosidase activity (Herrero et al., 1996).

The acidifying abilities of enterococci isolates at $30^{\circ} \mathrm{C}$ were in general low and only isolates did not lowered the $\mathrm{pH}$ of milk after $24 \mathrm{~h}$ of incubation to $\mathrm{pH}<5.0$. The drop in $\mathrm{pH}$ after $24 \mathrm{~h}$ was ranged between 1.05 and 1.51. Nevertheless, the drop in $\mathrm{pH}$ after $5 \mathrm{~h}$ of incubation of enterococci isolates was, in general, higher than that of lactobacilli at $6 \mathrm{~h}$, but there was a tendency for the strains to become slow after $5 \mathrm{~h}$.

A rapid decrease in $\mathrm{pH}$ during the initial step of cheese preparation is crucial importance in cheese manufacture, since it is essential for coagulation and prevention or reduction of the growth of adventitious microflora. The fast acidifying strains are good candidate in the dairy fermentation process as primary starter organisms, whereas, the poor acidifiers strains can be used as adjunct cultures depending on their other important properties, e. g., proteolytic and autolytic activity.

Our test isolates were characterized by different caseinolytic breakdown ability (Figure 2). All isolates exhibit proteolytic activities as revealed by clear halos on milk agar (showing $>2 \mathrm{~mm}$ hydrolysis zones in milk agar plate). These activities ranged between 2.30-5.51 meq Gly/l for L. lactis subsp. lactis isolates. The proteolytic activity of the enterococci isolates was measured at levels between 1.85 (E. faecium strain DN5) and 5.95 meq Gly/l (E. feacium isolate DT2).

The proteolytic activity of lactobacilli ranged between 1.70 ( $\mathrm{Lb}$. plantarum isolate DR22) and 5.7 meq Gly/l ( $L b$. rhamnosus isolate DR19).

The data reported here on proteolytic activity suggest that there was no relationship between the proteolytic and acidifying activities of the isolates, as also suggested by Bottazi (1962) and Fontina et al. (1998) for isolates of lactobacilli. Thus, isolates with the strongest acidifying abilities (lactobacilli isolates DT18, DR22 and DT23 and enterococci isolates DN1, DT4 and DN5) did not exhibit the highest proteolytic activities. Hence there were isolates with very low acidifying but high proteolytic activity (e.g. Lb. plantarum DR19) and isolates with high acidifying and protreolytic activities (for example, $L$. lactis subsp. lactis isolates DT11, DN12 and E. faecium isolate D06). The proteolytic system of Lactococcus has been studied for several years and consists of cell wall-bound proteinases and several peptidases (Bockelmann, 1995). Enzymes formed by Lactobacillus strains were studied in detail and many authors have described enzymes that were biochemically similar to those of Lactococcus and their importance for cheese ripening is obvious (Bockelmann, 1995). The proteolytic activity and acid production of enterococci during growth in milk are sometimes comparable to 
those of Steptococcus thermophilus (Gatti et al., 1994).

The proteolytic activity of dairy lactic acid bacteria is essential for the bacterial growth in milk and involved in the development of organoleptic properties of different fermented milk products (Axelsson, 1998; Christensen et al., 1999). The production of high quality fermented dairy products is dependent on proteolytic systems of starter bacteria, since peptidase and amino acids formed have a direct impact on flavour or serve as flavour precursors in these products. Several peptidases with different specificities have been identified in lactic acid bacteria; all peptidases have been found to be intracellular and liberated in fermented milk products after cell lysis (Law and Haandrikman, 1997; Axelsson, 1998).

\section{Autolytic Activity}

The ability of strains to lyse and subsequent release of their intracellular enzymes is a desirable trait during the ripening of cheese; the degree of autolysis is strain dependent (Wilkinson et al., 1994; El-Soda et al., 2000). The autolytic activities of strains were found among various isolates and were classified into three groups; poor, fair, and good, (Figure 3) according to the autolytic capacity of each genus as described by Ayad et al. (2004). For isolates with "good autolysis" $(L b$. rhamnosus DN13, DN14, DN15, DR19; Lb. plantarum DR20, DN16; L. lactis DN12, DR9; E. faecium DT2, DT4, DR6 and E. durans DN3) the autolysis rate ranged from $73 \%$ to $92 \%$ for lactobacilli isolates, from $37 \%$ to $38 \%$ for lactococci isolates, and from $40 \%$ to $56 \%$ for enterococci isolates. For isolates with "fair autolysis" (Lb. rhamnosus DR17; Lb. plantarum DT18; L. lactis DT11, DN8 and $E$. faecalis DN1, DR7) autolysis levels ranged from $57 \%$ to $58 \%$ for lactobacilli, $22 \%$ to $36 \%$ for lactococci and $30 \%$ to $34 \%$ for enterococci. The poor autolysis strains Lb. paracasei subsp. paracasei DT21, DT23; Lb. plantarum DR22; L. lactis DR10 and E. faecalis DN5, showed an autolytic rate ranging from $12 \%$ to $20 \%$ for lactobacilli, $9 \%$ for lactococci and $8 \%$ for enterococci.

Lactobacilli showed higher autolysis rate compared to enterococci and lactococci strains (Dako et al., 1995; ElSoda et al., 1995), they indicated that Lactobacillus autolysed more rapidly than Lactococcus strains. These results are comparable with the finding of Ayad (2001) who reported that several wild lactococci strains were found to be stable in milk cultures and during cheese ripening in contrast to industrial strains. The differences in the autolytic rate of some strains (figure 3) indicate the wide diversity among the strains. Cultures with high autolysis rate can be of importance for cheese manufacture because of faster release of their intracellular proteolytic and lipolytic enzymes, which will contribute to flavour formation in the manufacture of fermented dairy products (Wouters et al., 2002; Ayad et al., 2003). As reviewed by El-Soda et al. (1995), one of the most effective ways to accelerate cheese ripening can be the addition of adjunct cultures, mainly Lactobacillus ssp. and the selection of these cultures should be based on enzymes profiles and autolytic properties.

\section{Decarboxylase Activity}

All lactic acid bacteria strains tested in this study were screened for their ability to produce biogenic amines. None of them produced biogenic amines in our hands. Decarboxylating bacteria can find suitable conditions to proliferate and produce biogenic amines during ripening of cheese. Tyramine is the only biogenic amine produced after growth in milk by E. faecais and E. faecium in the presence of a pool of free amino acids as precursor (Giraffa et al., 1995). 
O. Hassaine et al.

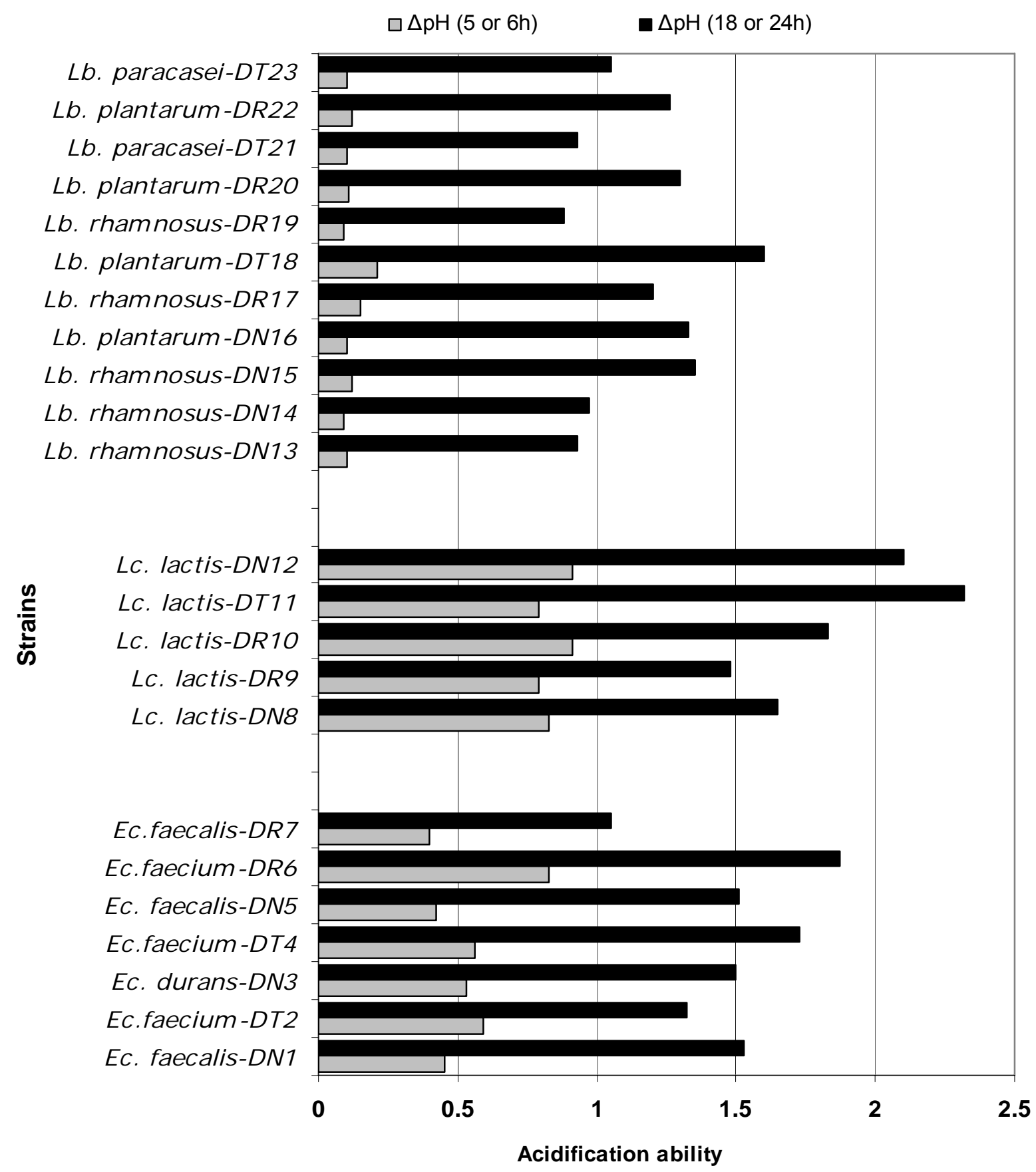

- The $\mathrm{pH}$ of the each isolate cultivated in skimmed milk was measured after $6 \mathrm{~h}$ for lactococci and lactobacilli and after $5 \mathrm{~h}$ for enterococci and after $18 \mathrm{~h}$ for lactococci and/or $24 \mathrm{~h}$ for lactobacilli and enterococci.

- DR: Dromedary milk of Reguibi breed; DT: Dromedary milk of Targui breed; DN: Dromedary milk of N'ajjer breeds.

Figure 1. Acidifying activities of lactic acid bacteria strains isolated from raw dromedary milks tested in this study. 
Emir. J. Food Agric. 2008. 20 (1): 46-59

http://www.cfa.uaeu.ac.ae/research/ejfa.htm

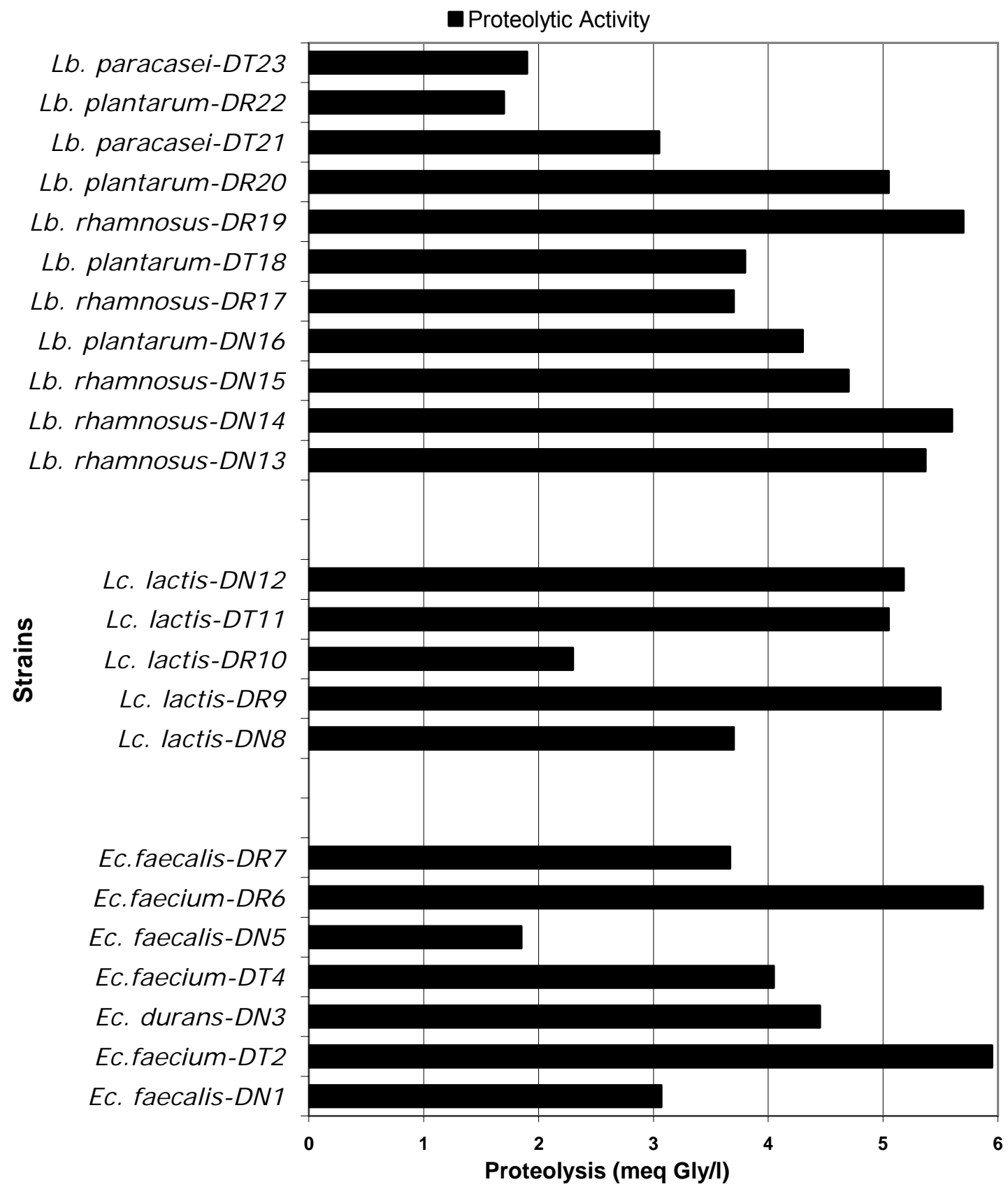

- The proteolytic activity was expressed as free amino groups with $\mathrm{mM}$ equivalency of Glycine per litre of milk (meq Gly/l).

- DR: Dromedary milk of Reguibi breed; DT: Dromedary milk of Targui breed; DN: Dromedary milk of N'ajjer breeds.

Figure 2. Proteolytic activities of lactic acid bacteria strains isolated from raw dromedary milks tested in this study, and were evaluated in the skimmed milk after $72 \mathrm{~h}$ of incubation at 507 nm after reaction with Cd-ninhydrin (Folkertsma and Fox, 1992). 
O. Hassaine et al.

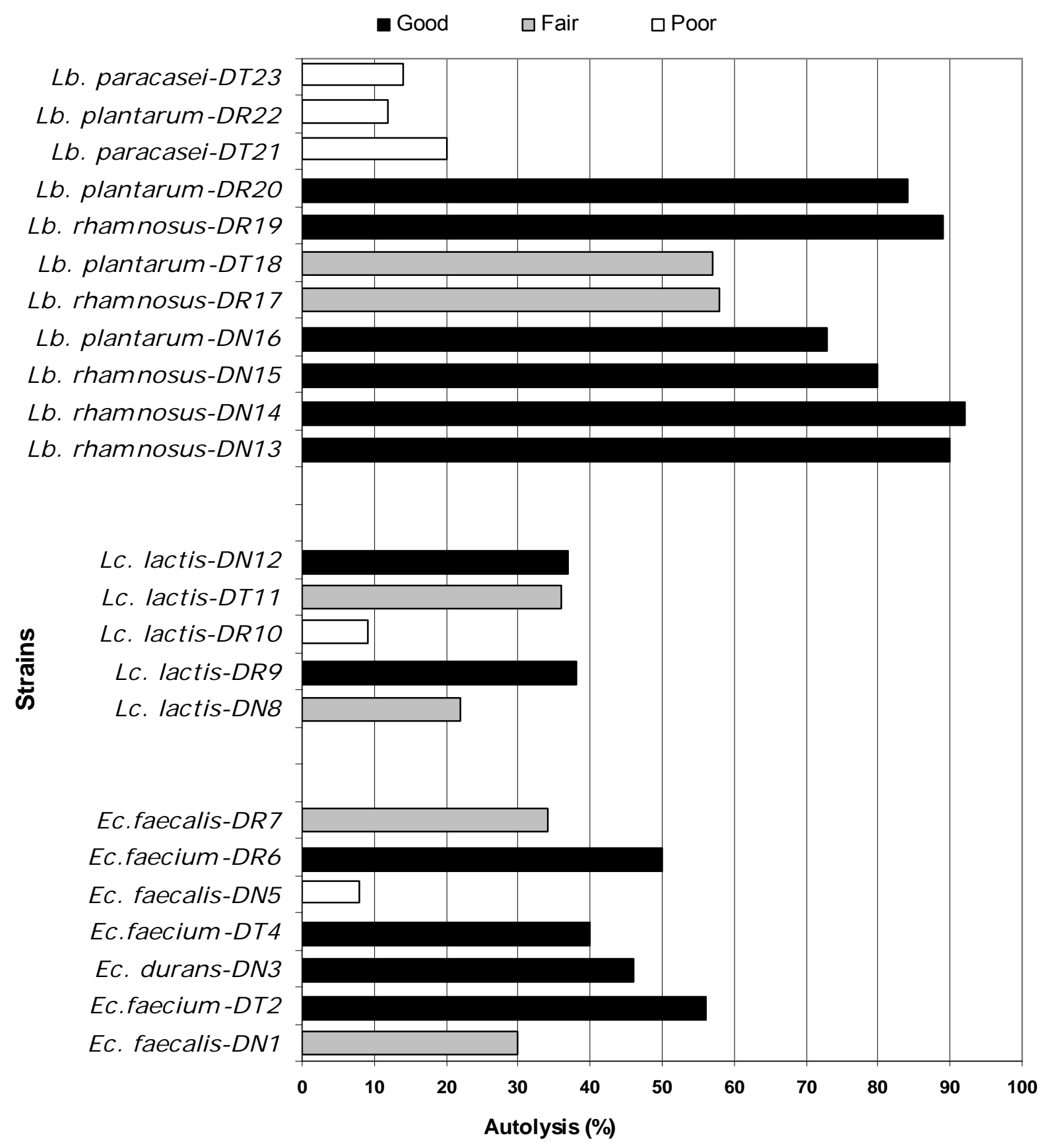

- The autolytic activity was determined as the percentage decrease in the $\mathrm{OD}_{650}$, and was ranked in accordance to the activity level of each genus; Good, Fair and Poor.

- DR: Dromedary milk of Reguibi breed; DT: Dromedary milk of Targui breed; DN: Dromedary milk of N'ajjer breeds.

Figure 3. Autolytic activities of lactic acid bacteria strains isolated from raw dromedary milks tested in this study. 


\section{References}

Axelsson, L. 1998. Lactic acid bacteria: classification and physiology. In: Salminen, S. and A. von Wright (Eds.). Lactic Acid Bacteria: Microbiology and Functional Aspects., pp. 1-72. New York, Marcel Dekker.

Ayad, E. H. E., S. Nashat, N. El-Sadek, H. Metwaly and M. El-Soda. 2004. Selection of wild lactic acid bacteria isolated from traditional Egyptian dairy products according to production and technological criteria Food Microbiology. 21:715-725.

Ayad, E. H. E., A. Verheul, P. Bruinenberg, J. T. M. Wouters and G. Smit. 2003. Starter culture development for improving the flavour of Proosdij-type Cheese. International Dairy Journal. 13:159168.

Ayad, E. H. E. 2001. Characterisation of lactococci isolated from natural niches and their role in flavour formation of cheese. Ph. D. Thesis, Wageningen Agricultural University, Wageningen, The Netherlands, ISBN: 90-5808-403-5.

Balows, A., H. Truper, M. Dvorkin, W. Harder and K. Schleifer. 1991. In: the Procaryotes, Vol. II. pp. 1468, 1485, 1564. New York: Springer-Verlag.

Bissonnette, F., S. Labrie, H. Deveau, M. Lamoureux and S. Moineau. 2000. Characterization of mesophilic mixed starter cultures used for manufacture of aged Cheddar cheese. Journal of Dairy Science. 83: 620-627.

Bockelmann, W. 1995. The proteolytic system of starter and non-starter bacteria: Components and their importance for cheese ripening.
International Dairy Journal. 5:977994.

Bottazzi, V. 1962. Il potere proteolytico dei lactobacilli e il processo di maturazione dei formaggi. Latte. 36:597-603.

Bouton, Y., P. Guyot, A. Dasen and G. Grappin. 1993. Activité protéolytique de souches de lactobacilles thermophiles isolées de levains et de Comté. I. Validation sur minifromages des techniques de laboratoire. Le lait. 73:265-279.

Boutrou, R., A. Sepulchre, J. C. Gripon and V. Monnet. 1998. Simple tests for predicting the lytic behavior and proteolytic activity of lactococcal strains in cheese. Journal of Dairy Science. 81:2321-2328.

Christensen, J. E., E. G. Dudley, J. A. Pederson and L. J. Steelz. 1999. Peptidases and amino acid catabolism in lactic acid bacteria. Antonie van Leeuwenhoek. 76:217-246.

Collins, M. D., U. Rodriquez, C. Ash, M. Aguirre, J. A. E. Farrow, A. Martinez-Murcia, B. A. Phillips, A. M. Williams and S. Wallbanks. 1991. Phylogenic analysis of the genus Lactobacillus and related lactic acid bacteria as determined by reverse transcriptase sequencing of $16 \mathrm{~S}$ rRNA. FEMS Microbiology letters. 77:5-12.

Dako, E., M. El-Soda, J. C. Vuillemard and R. E. Simard. 1995. Autolytic properties and aminopeptidases activities of lactic acid bacteria. Food Research International. 28: 503.

De Man, J., M. Rogosa and E. Sharpe. 1960. A medium for the cultivation of 
lactobacilli. Journal of Applied Bacteriology. 23:130-135.

Devriese, L. A., B. Pot and M. D. Collins. 1991. Phenotypic identification of the genus Enterococcus and differentiation of phylogenetically distinct enterococcal species and species groups. Journal of Applied Microbiology. 75:399-408.

Durlu-Ozkaya, F., V. Xanthopoulos, N. Tunail and E. Litopoulou-Tzanetaki. 2001. Technologically important properties of lactic acid bacteria isolated from Beyas cheese made from raw ewes' milk. Journal of Applied Microbiology. 91:861-870.

El-Soda, M., S. A. Madkor and P. S. Tong. 2000. Evaluation of commercial adjuncts for use in cheese ripening: 4. Comparison between attenuated and not attenuated lactobacilli. Milchwissenschaft. 55 (5):260-263.

El-Soda, M., N. Farkye, J. Vuillemard, R. Simard, N. Olson, W. El Kholy, E. Dako, E. Medrano, M. Gaber and L. Lim. 1995. Autolysis of lactic acid bacteria. Impact on flavour development in cheese. In: Charalambous G. (Ed). Food Flavour: Generation Analysis and Process Influence. Amsterdam, The Netherlands. pp. 2205-2223. Elsevier Science B. V.

Fitzsimmons, N. A., T. M. Cogan, S. Condon and T. Beresford. 1999. Phenotypic and genotypic characterization of non-starter lactic acid bacteria in mature Cheddar cheese. Applied and Environmental Microbiology. 65:3418-3426.

Folkertsma, B and P. F. Fox. 1992. Use of Cd-ninhydrin reagent to assess proteolysis in cheese during ripening.
Journal of Dairy Research. 59:217224.

Fontina, M. G., G. Nicastro, D. Garminati, E. Neviani and P. L. Manachini. 1998. Lactobacillus helviticus heterogeneity in natural cheese starters: the diversity in phenotypic characteristics. Journal of Applied Microbiology. 84:72-80.

Gatti, M., E. Fornasari, D. Garni, G. Giraffa and E. Neviani. 1994. Gli enterococchi nei formaggi italiani: attivita biochimiche e signifato technologica. Industria del Latte. 30:11-27.

Giraffa, G., G. Pepe, F. Locci, E. Neviani and D. Carminati. 1995. Haemolytic activity production of thermonuclease and biogenic amines by dairy enterococci. Italian Journal of Food Science. 7:339-347.

Gordon, R. E., W. C. Haynes and C. HN. Pang. 1973. The Genus Bacillus, Hand-book no. 427. United States Department of Agriculture, Washington, DC.

Harrigan, W. F. 1998. Laboratory Methods in Food Microbiology, $3^{\text {rd }}$ edition, London. Academic Press.

Herrero, M., Mayo., B. Gonzalez and J. E. Suarez. 1996. Evaluation of technologically important trains in lactic acid bacteria isolated from spontaneous fermentations. Journal of Applied Microbiology. 81:565-570.

Huggins, A. R and W. E. Sandine. 1984. Differentiation of fast and slow milkcoagulating isolates in strains of streptococci. Journal of Dairy Sciences. 67:1674-1679.

Joosten, H and M. D. Northolt. 1989. Detection growth, and amine- 
Emir. J. Food Agric. 2008. 20 (1): 46-59

http://www.cfa.uaeu.ac.ae/research/ejfa.htm

producing capacity of lactobacilli in cheese. Applied Environmental and Microbiology. 55:2356-2359.

Knoess, K. H. 1980. Milk production of the dromedary. In: camels. pp. 201214. Symposium, Sudan. International Foundation for Science (IFS).

Law, J and A. Haandrikman. 1997. Proteolytic enzymes of lactic acid bacteria. International. Dairy Journal. $7: 1-11$.

Leisner, J. J., G. Rusul, B. W. Wee, H. C. Boo and K. Mohammad. 1997. Microbiology of Chili Bo. A popular Malaysian food ingredient. Journal of Food Protection. 60:1235-1240.

Manero, A and A. R. Blanch. 1999. Identification of Enterococcus ssp. with a biochemical key. Applied Environmental and Microbiology. 65:4425-4430.

McKay, L. L., K. A. Baldwin and J. D. Efstathiou. 1976. Transductional evidence for plasmid linkage of lactose metabolism in Streptococcus lactis C2. Applied Environmental and Microbiology. 32:722-728.

Samelis, J., F. Maurogenakis and J. Metaxopoulos. 1994. Characterization of lactic acid bacteria isolated from naturally fermented Greek dry salami. International Journal of Food Microbiology. 23:179-196.

Schleifer, K. H and R. Kilpper-Balz. 1984. Transfer of Streptococcus faecalis and Streptococcus faecium to the genus Enterococcus nom. Rev. as Enterococcus faecalis comb. Nov. \& Enterococcus faecieum comb. Nov. International Journal of Systematic Bacteriology. 34:31-34.
Schleifer, K. H., J. Kraus, C. Dvorac, R. Kilpper-Balz, M. D. Collins and W. Fisher. 1985. Transfer of Streptococcus lactis and related streptococci to the genus Lactococcus gen. nov. Systematic Applied Microbiology. 6:183-195.

Sharpe, M. E. 1979. Identification of the lactic acid bacteria. In: Identification Methods for Microbiologists. In: Skinner, F. A. and D. W. (Eds). pp. 233-259. London: Academic Press.

Terzaghi, B. K and W. E. Sandine. 1975. Improved medium for lactic streptococci and their bacterophage. Applied Microbiology. 29:807-813.

Thiboutot, H., E. Dako, M. El-Soda, J. C. Vuillemard, N. Power and R. E. Simard. 1995 Influence of heat and freeze shocking on the autolysis and peptidase activities of Lactobacillus casei. Milchwissenschaft. 50:448-452.

Thomas, T. D., (1973) Agar medium for differentiation of Streptococcus cremoris from the other bacteria. $N$. Z. J. Dairy Sci. Technol. 8:70-71.

Wilkinson, M. G., T. P. Guinee, D. M. O'Callaghan and P. F. Fox. 1994 Autolysis and proteolysis in different strains of starter bacteria during cheese ripening. Journal of Dairy Research. 61:249-262.

Wouters, J. T. M., E. H. E Ayad, J. Hugenholtz and G. Smit. 2002. Microbes from raw milk for fermented dairy products. International Dairy Journal. 12:91109.

Yagil, R. 1982. Camels and camel milk. Rome: Food and Agriculture Organization (FAO) Animal Production and Health, Paper $\mathrm{N}^{\circ}$. 26, pp. 14-19. 
O. Hassaine et al.

Zourari, A., S. Roger, C. Chabanet and artisanaux grecs. Souches de M. Desmazeaud. 1991. Caractérisation de bactéries lactiques thermophiles isolées de yaourts Streptococcus salivarius subsp. thermophilus. Lait. 71:445-461. 